\title{
Serine Racemase Deletion Protects Against Cerebral Ischemia and Excitotoxicity
}

\author{
Asif K. Mustafa, ${ }^{1}$ Abdullah S. Ahmad, ${ }^{2}$ Emil Zeynalov, ${ }^{2}$ Sadia K. Gazi, ${ }^{1}$ Gautam Sikka, ${ }^{2}$ Jeffrey T. Ehmsen, ${ }^{1}$ \\ Roxanne K. Barrow, ${ }^{1}$ Joseph T. Coyle, ${ }^{5,6}$ Solomon H. Snyder, ${ }^{1,3,4}$ and Sylvain Doré ${ }^{2,3}$ \\ ${ }^{1}$ Solomon H. Snyder Department of Neuroscience and Departments of ${ }^{2}$ Anesthesiology and Critical Care Medicine, ${ }^{3}$ Pharmacology and Molecular Sciences, \\ and ${ }^{4}$ Psychiatry and Behavioral Sciences, Johns Hopkins University School of Medicine, Baltimore, Maryland 21205, and ${ }^{5}$ Department of Psychiatry and \\ ${ }^{6}$ Laboratory for Psychiatric and Molecular Neuroscience, Harvard Medical School, Belmont, Massachusetts 02478
}

D-Serine, formed from L-serine by serine racemase (SR), is a physiologic coagonist at NMDA receptors. Using mice with targeted deletion of SR, we demonstrate a role for D-serine in NMDA receptor-mediated neurotoxicity and stroke. Brain cultures of SR-deleted mice display markedly diminished nitric oxide (NO) formation and neurotoxicity. In intact SR knock-out mice, NO formation and nitrosylation of NO targets are substantially reduced. Infarct volume following middle cerebral artery occlusion is dramatically diminished in several regions of the brains of SR mutant mice despite evidence of increased NMDA receptor number and sensitivity.

\section{Introduction}

D-Serine, formed by serine racemase (SR), which converts L-serine to D-serine, is a physiologic coagonist with glutamate at NMDA receptors (Wolosker, 2006). D-Serine is primarily localized to glia that ensheathe neurons, whereas SR occurs both in glia and neurons (Wolosker, 2006). SR is dynamically regulated by glutamate. Thus, activation of metabotropic glutamate receptors leads to cleavage of phosphatidylinositol $(4,5)$-bisphosphate (PIP2) by phospholipase C (PLC), thereby diminishing inhibition by PIP2 of SR (Mustafa et al., 2009). Glutamate receptor interacting protein (GRIP), normally bound to AMPA receptors, dissociates upon neuronal depolarization to bind to and activate SR (Kim et al., 2005). Glutamate/D-serine activation of NMDA receptors leads to formation of nitric oxide (NO), which nitrosylates and inactivates SR, providing a feedback homeostatic regulation (Mustafa et al., 2007). D-Serine is degraded by D-amino acid oxidase, which, along with its associated protein G72, has been linked to schizophrenia (Coyle, 2006).

To elucidate physiologic roles of D-serine, we created SRdeleted mice (Basu et al., 2009). The mutant mice display an 85\% reduction in D-serine levels with alterations in NMDA neurotransmission and decreased long term potentiation (LTP). However, both NMDA transmission and LTP are enhanced by exogenous application of D-serine in the mutant mice, suggesting receptor supersensitivity. Male, but not female, SR knock-outs exhibit spatial memory deficits (Basu et al., 2009). The reasons for this gender discrepancy are not entirely clear. In the present

Received Aug. 31, 2009; revised Nov. 11, 2009; accepted Nov. 20, 2009.

This study was supported by a National Institutes of Health (NIH) National Research Service Award (1 F30 MH074191-01A2) to A.K.M., NIH Grants AG022971 (to S.D.) and P50 MH060450 and MH-572901 (to J.T.C.), and U.S. Public Health Service Grant MH18501 and Research Scientist Award DA00074 (to S.H.S.). We thank Maimon Hubbi and Andrea Benedict for their help.

Correspondence should be addressed to Solomon H. Snyder or Sylvain Doré, Johns Hopkins University, 725 North Wolfe Street, Baltimore, MD 21205, E-mail: ssnyder@jhmi.edu or sdore@jhmi.edu.

DOI:10.1523/JNEUROSCI.4297-09.2010

Copyright $\odot 2010$ the authors $\quad 0270-6474 / 10 / 301413-04 \$ 15.00 / 0$ study, we have examined pathophysiologic consequences of SR deletion. We show marked diminution in neuronal death following oxygen-glucose deprivation of $\mathrm{SR}^{-1-}$ brain cultures and substantially less brain damage following middle cerebral artery occlusion. These changes are accompanied by pronounced declines in NO formation and nitrosylation of its targets. SR ${ }^{-1-}$ mice also display NMDA receptor supersensitivity, as evidenced by increased NR1 receptor protein levels and enhanced NMDAelicited brain damage.

\section{Materials and Methods}

Animals. Biochemical experiments involving animals were performed on brains removed from 8 -10-week-old male wild-type, SR ${ }^{-1-}$ (Basu et al., 2009), and neuronal NO synthase (nNOS) ${ }^{-1-}$ animals. Animals were maintained on a $12 \mathrm{~h} \mathrm{light/dark} \mathrm{cycle} \mathrm{at} \mathrm{a} \mathrm{room} \mathrm{temperature} \mathrm{of} 23^{\circ} \mathrm{C}$, with ad libitum access to food and water. All animal-use procedures were in accordance with the National Institutes of Health Guide for the Care and Use of Laboratory Animals and approved by the Johns Hopkins University Animal Care and Use Committee.

Antibodies. Antibodies to SR and nNOS were from BD Biosciences, antibodies to NMDA receptor NR1, $\beta$-tubulin, and actin were from Millipore, and antibodies to GAPDH were from Calbiochem.

Oxygen-glucose deprivation. The oxygen-glucose deprivation (OGD) experiments were done as described previously (Eliasson et al., 1997). Briefly, cortical cultures grown for 12-14 d in Neurobasal media supplemented with horse serum at $37^{\circ} \mathrm{C}$ were treated with $10 \mathrm{mM} \mathrm{L}$-serine for $5 \mathrm{~h}$ and then exposed to a gas mixture of $5 \% \mathrm{CO}_{2} / 95 \% \mathrm{~N}_{2}$ in an airtight chamber with OGD buffer containing (in $\mathrm{mm}$ ) $125 \mathrm{NaCl}, 3 \mathrm{KCl}, 1.6$ $\mathrm{CaCl}_{2}, 0.2$ arginine, 25 HEPES, $\mathrm{pH} 7.4,1 \mathrm{D}$-glucose, and $1.25 \mathrm{Na}_{2} \mathrm{HPO}_{4}$ for $1 \mathrm{~h}$ at $37^{\circ} \mathrm{C}$. The OGD solution was then replaced with regular neuronal culture media and the cells grown for $24 \mathrm{~h}$ at $37^{\circ} \mathrm{C}$. Toxicity was assayed by microscopic examination with computer-assisted cell counting following staining of all nuclei with $1 \mu \mathrm{g} / \mathrm{ml}$ Hoechst 33258 stain and dead cells with $7 \mu \mathrm{M}$ propidium iodide. Total and dead cells were counted, and the percentage of cell death was determined. Experimenters were blinded.

Middle cerebral artery occlusion. All mice were 8-10-week-old male $\mathrm{SR}^{-1-}$ and matched wild-type littermates weighing between 20 and $25 \mathrm{~g}$. Transient focal ischemia was induced by a 90 min occlusion of the middle 
cerebral artery (MCA) in wild-type and $\mathrm{SR}^{-1-}$ mice, as described previously (Zeynalov and Doré, 2009). Successful occlusion was confirmed by an $87-90 \%$ reduction in cerebral blood flow (CBF), as measured by Laser-Doppler flowmetry. After reperfusion was begun and isoflurane anesthesia was discontinued, the animals were kept in a humidified thermoregulated chamber until they became completely awake (usually within $20-30 \mathrm{~min}$ ). At $24 \mathrm{~h}$ of reperfusion, the mice were deeply anesthetized and the brains processed for analysis of infarct volume. Brains were harvested, sliced into 2-mm-thick sections and stained with $1 \%$ 2,3,5-triphenyltetrazolium chloride. Infarct volume was calculated as a percentage of the contralateral hemisphere and corrected for swelling.

NMDA excitotoxicity assays. Weight and rectal temperature of each mouse was recorded before the surgical procedure. Anesthesia was induced with $3.0 \%$ halothane and thereafter maintained at $1.0 \%$ halothane. Each mouse was mounted on a stereotaxic frame, and $0.3 \mu \mathrm{l}$ of NMDA ( $67 \mathrm{~mm}$ ), prepared in PBS, was injected into the right striatum over a 2 min period; the needle was left in situ for an additional 5 min to prevent back flow. After injections, mice were placed in a humidified, thermoregulated chamber maintained at $31^{\circ} \mathrm{C}$ and then returned to their cages after full recovery from anesthesia. Throughout the experimental procedure, mouse rectal temperature was monitored and maintained at $37.0 \pm 0.5^{\circ} \mathrm{C}$. Fortyeight hours after injection, brains were harvested and immediately frozen in 2-methylbutane (precooled over dry ice); $20 \mu \mathrm{m}$ sections were cut on a cryostat and stained with cresyl violet to measure lesion volume. Brain sections were photographed and analyzed with SigmaScan Pro 5.0 (Systat Software).

NO generation. NO formation was assessed in cortical neurons cultured for $12-14 \mathrm{~d}$ at $37^{\circ} \mathrm{C}$ or from 6-8-week-old mouse brains. Cultures, treated with $10 \mathrm{~mm}$ L-serine for $5 \mathrm{~h}$, were incubated for 5 min with $2 \mu \mathrm{M}$ 4-amino-5-methylamino-2' 7 '-difluorofluorescein diacetate (DAF-FM DA; Invitrogen), a specific dye that emits fluorescence intracellularly only upon interaction with NO. The cells were then gently washed with fresh media and subjected to immunofluorescence microscopy with excitation wavelength at $495 \mathrm{~nm}$ and emission wavelength at $515 \mathrm{~nm}$ for $15 \mathrm{~min}$ with continuous signal recording. For measurements from mouse tissue, brains were sliced into 300 $\mu \mathrm{m}$ sections using a McIlwain Tissue Chopper and equilibrated with $95 \%$ oxygen $/ 5 \% \mathrm{CO}_{2}$ at $37^{\circ} \mathrm{C}$ for $30 \mathrm{~min}$ in pre-oxygenated artificial CSF (ACSF) buffer containing (in $\mathrm{mM}$ ) $125 \mathrm{NaCl}, 3 \mathrm{KCl}, 1.6 \mathrm{CaCl}_{2}, 0.2$ arginine, 25 HEPES, pH 7.4, 11 D-glucose, and $1.25 \mathrm{Na}_{2} \mathrm{HPO}_{4}$. The slices were then incubated with $0.2 \mathrm{~mm}$ DAF-FM DA at $37^{\circ} \mathrm{C}$ for $1 \mathrm{~h}$, following which they were mechanically lysed and centrifuged at $14,000 \mathrm{rpm}$ for $10 \mathrm{~min}$, and the protein concentration was measured with the BioRad protein assay solution. Lysate $(0.25 \mathrm{mg}$ of protein), reconstituted in $1 \mathrm{ml}$ of $20 \mathrm{~mm}$ ACSF buffer at $\mathrm{pH}$ 7.4 , was then subjected to fluorescence measurements to detect $\mathrm{NO}$ generation as above.

S-nitrosylation biotin switch assay. The assay was carried-out as described previously (Jaffrey and Snyder, 2001) but with minor modifications. Briefly, brain tissue from wild-type, $\mathrm{SR}^{-1-}$, and $\mathrm{nNOS}^{-1-}$ mice was homogenized in HEN buffer (250 mm HEPES-NaOH, pH 7.7, 1 mm EDTA, 0.1 mm Neocuproine) supplemented with $100 \mu \mathrm{M}$ deferoxamine (DFO) and centrifuged at $13,000 \times g$ for $20 \mathrm{~min}$ at $4^{\circ} \mathrm{C}$. Lysate $(0.24 \mathrm{mg}$ of protein) was added to

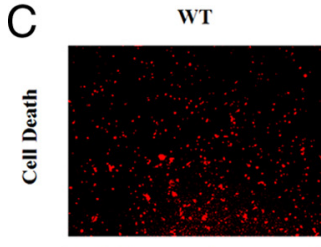

B
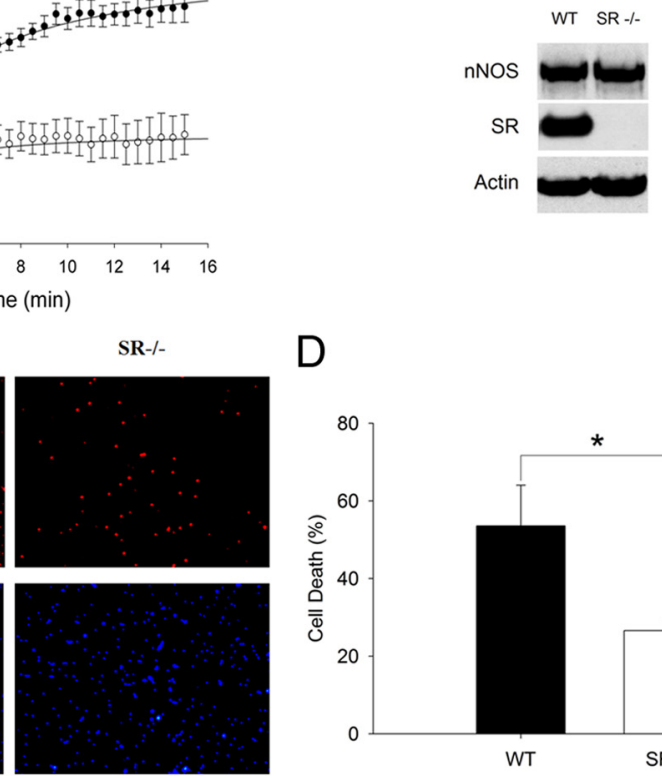

D

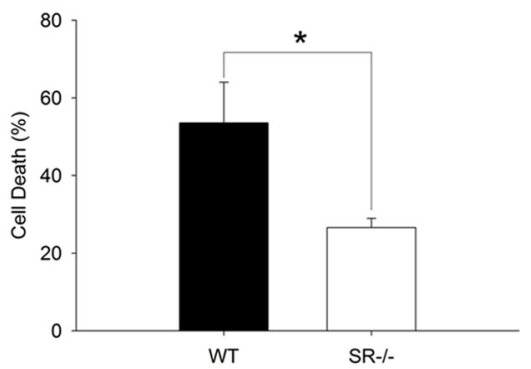

Figure 1. Neurotoxicity is markedly reduced in SR-deleted cerebral cortical cultures. $\boldsymbol{A}$, N0 generation, measured using the NO-specific dye DAF-FM DA, is markedly diminished in SR ${ }^{-1-}$ cultures. $\boldsymbol{B}, \mathrm{nNOS}$ protein expression is similar in wild-type (WT) and (label for dead cells) to Hoechst 33258 stain (nuclear label for all cells). D, Quantitation of cell death from 0GD shows a 50\%

A

Figure 2. Synthesis of nitric oxide and protein S-nitrosylation are decreased in $S R^{-1-}$ brains. $A$, N0 generation in wild-type generation. $\boldsymbol{B}$, S-nitrosylation (SNO) of GAPDH is markedly reduced in $\mathrm{SR}^{-1-}$ brain and absent in $\mathrm{nNOS}{ }^{-1-}$ preparations in wild-type versus SR ${ }^{-1-}$ brains reveals a pronounced reduction (70-90\%) in S-nitrosylation of GAPDH, $\beta$-tubulin, and the NR1 subunit of the NMDA receptor in SR-deleted animals. ${ }^{*} p<0.05,{ }^{* *} p<0.01,{ }^{* * *} p<0.001$.

blocking buffer [HEN buffer plus 25\% SDS and $20 \mathrm{~mm}$ methymethanethiosulfonate (MMTS)] at $50^{\circ} \mathrm{C}$ for $20 \mathrm{~min}$ with frequent vortexing. The MMTS was then removed by acetone and the proteins precipitated at $-20^{\circ} \mathrm{C}$ for $20 \mathrm{~min}$. After acetone removal, the proteins were resuspended in HENS buffer (HEN + 1\% SDS). To the suspension was added $1 \mathrm{~mm} \mathrm{~N}$-[6(biotinamido)hexyl]-3'-(2'-pyridyldithio)-propionamide (biotin-HPDP) in DMSO with $1 \mathrm{~mm}$ ascorbic acid. After incubation for $2 \mathrm{~h}$ at $25^{\circ} \mathrm{C}$, biotinylated proteins were precipitated by streptavidin-agarose beads that were then washed with HENS buffer. The biotinylated proteins were eluted by SDS-PAGE sample buffer and subjected to Western blot analysis. For quantitation of protein $S$-nitrosylation, the signals were densitometrically analyzed using the software EagleSight 3.2 (Stratagene) and Odyssey 2.1 (Li-Cor).

Cell culture. Cortical neuronal cultures were obtained as described previously (Kartvelishvily et al., 2006).

$\mathrm{L}$-Serine measurements. L-Serine from wild-type and $S R^{-1-}$ cortical neuronal cultures, treated with $10 \mathrm{~mm} \mathrm{~L}$-serine for $5 \mathrm{~h}$, was measured as described earlier (Kartvelishvily et al., 2006). 
A

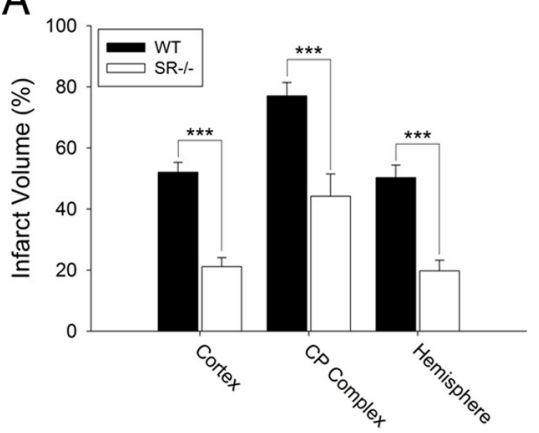

B

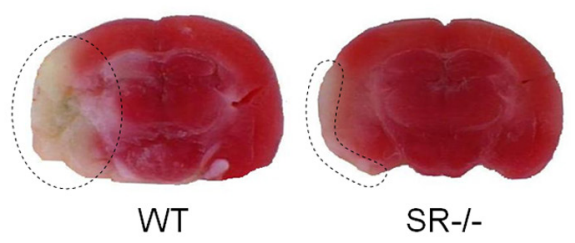

Figure 3. SR deletion protects against focal cerebral ischemia. $A$, Infarct volume following MCAO is reduced by $61 \%$ in the cerebral hemispheres, $60 \%$ in the cerebral cortex, and $43 \%$ in the caudate-putamen $(\mathrm{CP})$ region of the $\mathrm{SR}^{-1-}$ mice compared with wild-type (WT) littermate controls ( $n=9$ animals each). $\boldsymbol{B}$, Representative images of a wild-type and SR ${ }^{-1-}$ brain $24 \mathrm{~h}$ post-MCA0.SR ${ }^{-1-}$ mice display marked reduction in infarct area (contours delineated by dotted lines) compared with wild-type littermates. ${ }^{*} p<0.05,{ }^{* *} p<0.01,{ }^{* * *} p<0.001$

A

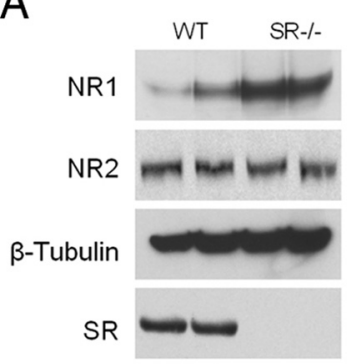

B

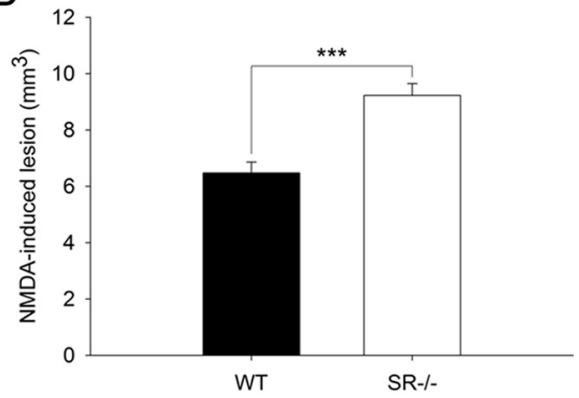

C

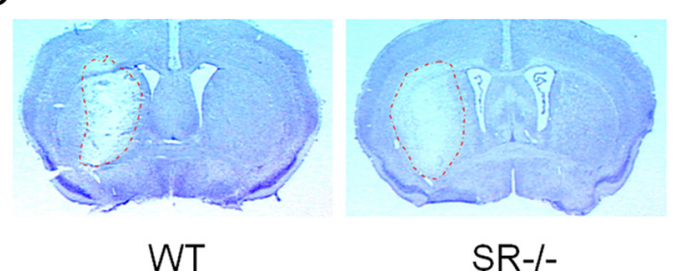

Figure 4. $S R^{-1-}$ mice display NMDA receptor supersensitivity. $A$, NMDA receptor NR1, but not NR2, subunit expression is increased in $\mathrm{SR}^{-1-}$ brains. $\boldsymbol{B}$, NMDA-elicited lesion volume is increased by nearly $50 \%$ in the striatum of $\mathrm{SR}^{-1-}$ animals compared with wild-type (WT) littermate controls ( $n=15$ animals each). $C$, Representative images of a wild-type and SR ${ }^{-1-}$ brain post-NMDA injection into the corpus striatum. SR ${ }^{-1-}$ mice display increased lesion area (contours delineated by dotted lines) compared with wild-type littermates. ${ }^{*} p<0.05$, ${ }^{* *} p<0.01$, ${ }^{* * *} p<0.001$.

Statistical analysis. All data are expressed as means \pm SEM of three independent experiments, each performed in triplicate unless otherwise indicated. Data were analyzed by unpaired Student's $t$ test.

\section{Results}

Diminished neurotoxicity in $\mathrm{SR}^{-1-}$ cerebral cortical cultures In $\mathrm{SR}^{-1-}$ cerebral cortical cultures, $\mathrm{D}$-serine levels are reduced $\sim 90 \%$, resembling findings in intact mouse brain (Basu et al., 2009). NO generation by the $\mathrm{SR}^{-1-}$ cultures is diminished by $\sim 50 \%$ despite no change in nNOS protein levels (Fig. $1 A, B$ ). Oxygen-glucose deprivation neurotoxicity is $\sim 50 \%$ lower in $\mathrm{SR}^{-1-}$ cultures as monitored by propidium staining (Fig. 1C,D).

\section{NO generation and protein $S$-nitrosylation are reduced in $\mathrm{SR}^{-1-}$ brains}

We examined the disposition of NO signaling and neurotoxicity in intact animals. NO generation is $70 \%$ lower in whole brain of $\mathrm{SR}^{-1-}$ animals compared with a $95 \%$ reduction in $\mathrm{nNOS}^{-1-}$ animals (Fig. $2 A$ ). NO signals in major part by $S$-nitrosylating a variety of protein targets (Hess et al., 2005). The diminished NO levels are accompanied by reductions in nitrosylation of $\sim 90 \%, 70 \%$, and $75 \%$ of the NO targets $\beta$-tubulin, GAPDH, and the NR1 subunit of NMDA receptors, respectively (Fig. $2 B, C$ ), extending our preliminary observations of reduced $\beta$-tubulin and GAPDH nitrosylation in $\mathrm{SR}^{-/-}$mice (Basu et al., 2009). This profound reduction in nitrosylation emphasizes the intimate linkage of D-serine-associated NMDA neurotransmission with $\mathrm{NO}$ signaling.

\section{SR deletion protects against focal cerebral ischemia}

We monitored stroke by assessing infarct volume following transient MCA occlusion (MCAO) (Fig. $3 A, B$ ). In $\mathrm{SR}^{-1-}$ animals, infarct volume is reduced by $50-60 \%$ in cerebral cortex, caudate-putamen, and cerebral hemisphere. The lesser neurotoxicity of brain cultures and diminished MCAO damage in SR mutants fits with diminished NMDA neurotransmission.

\section{$\mathrm{SR}^{-/-}$mice display NMDA receptor supersensitivity}

Neurotransmitter deficiency is often associated with receptor supersensitivity that may be manifested in increased levels of receptor protein, as exemplified for dopamine receptors (Kostrzewa et al., 2008). Because of the extremely high levels of endogenous glutamate derived from multiple sources, relationships of glutamate deficit to receptor sensitivity have not been readily studied. Nonetheless, a study by Nong et al. (2003) demonstrate that the concurrent binding of D-serine (or glycine) and glutamate prime NMDA receptor internalization. It is therefore conceivable that in the absence of $\mathrm{D}$-serine, surface expression of NMDA receptors will likely be increased, leading to receptor supersensitivity. In our earlier study of SR deleted mice, neurophysiologic experiments revealed supersensitivity of NMDA neurotransmission and LTP to D-serine stimulation (Basu et al., 2009). In SR ${ }^{-/-}$corpus striatum, we observe a fourfold increase in levels of NR1 NMDA receptor protein with no change in NR2 protein (Fig. $4 A$ ). To assess the functional consequences of increased receptor number, we injected NMDA directly into the striatum of $\mathrm{SR}^{-/-}$animals and detected a 50\% augmentation in NMDA-elicited lesion volume (Fig. $4 B, C)$.

\section{Discussion}

In summary, our study of SR-deleted mice reveals a major regulatory influence of SR-generated D-serine upon NO disposition and neurotoxicity. The pronounced decline of NO formation and nitrosylation of its targets in the mutant mice indicates a greater dependence of NO disposition upon D-serine-associated NMDA neurotransmission than has been previously appreciated. Abundant evidence has implicated overproduction of NO in neurotoxicity, 
although under some circumstances NO may be neuroprotective (Hara and Snyder, 2007).

The marked reduction in infarct volume of $\mathrm{SR}^{-1-}$ animals following MCAO is comparable to protection against stroke damage associated with pharmacologic blockade of NMDA receptors (Lipton, 2006). NMDA receptor antagonists, however, elicit adverse effects that have precluded clinical application in stroke therapy (Vallance and Leiper, 2002; Lipton, 2006). Conceivably, selective inhibition of D-serine formation by SR inhibitors would diminish acute stroke damage with fewer undesirable effects. Thus, SR deleted mice appear generally healthy with minimal neurocognitive abnormalities (Basu et al., 2009), whereas complete genetic deletion of NMDA receptors is lethal (Mohn et al., 1999).

Because of the difficulties in manipulating glutamate levels, their influences upon NMDA receptor supersensitivity have not been examined in depth. Our findings of a $400 \%$ increase in numbers of NR1 subunits in $\mathrm{SR}^{-1-}$ mice associated with increased NMDA-elicited brain damage provides evidence that receptor occupancy by D-serine is an important determinant of receptor sensitivity. Recently, Inoue et al. (2008) reported no alterations in NR1 levels in the cortex of SR ${ }^{-1-}$ animals and $40 \%$ decrease in cortical damage following NMDA injections. Reasons for the discrepancies between these findings and ours may reflect a variety of factors, including their use of the cerebral cortex $24 \mathrm{~h}$ following NMDA injection and our use of the striatum $48 \mathrm{~h}$ following NMDA injection as well as differences in NMDA dose.

It is striking that $\mathrm{SR}^{-1-}$ mice display less stroke damage despite increased NMDA receptor sensitivity. Presumably with MCAO, levels of D-serine are rate limiting so that the increased glutamate release associated with MCAO is less capable of overstimulating receptors. Direct injections of NMDA may expose receptors to overwhelming stimulation. Moreover, needle damage may lead to substantial release of endogenous glycine, which compensates for the loss of $\mathrm{D}$-serine.

\section{References}

Basu AC, Tsai GE, Ma CL, Ehmsen JT, Mustafa AK, Han L, Jiang ZI, Benneyworth MA, Froimowitz MP, Lange N, Snyder SH, Bergeron R, Coyle JT (2009) Targeted disruption of serine racemase affects glutamatergic neurotransmission and behavior. Mol Psychiatry 14:719-727.

Coyle JT (2006) Substance use disorders and schizophrenia: a question of shared glutamatergic mechanisms. Neurotox Res 10:221-233.
Eliasson MJ, Sampei K, Mandir AS, Hurn PD, Traystman RJ, Bao J, Pieper A, Wang ZQ, Dawson TM, Snyder SH, Dawson VL (1997) Poly(ADPribose) polymerase gene disruption renders mice resistant to cerebral ischemia. Nat Med 3:1089-1095.

Hara MR, Snyder SH (2007) Cell signaling and neuronal death. Annu Rev Pharmacol Toxicol 47:117-141.

Hess DT, Matsumoto A, Kim SO, Marshall HE, Stamler JS (2005) Protein $S$-nitrosylation: purview and parameters. Nat Rev Mol Cell Biol 6:150-166

Inoue R, Hashimoto K, Harai T, Mori H (2008) NMDA- and $\beta$-amyloid ${ }_{1-42^{-}}$ induced neurotoxicity is attenuated in serine racemase knock-out mice. J Neurosci 28:14486-14491.

Jaffrey SR, Snyder SH (2001) The biotin switch method for the detection of S-nitrosylated proteins. Sci STKE 2001:PL1.

Kartvelishvily E, Shleper M, Balan L, Dumin E, Wolosker H (2006) Neuronderived $\mathrm{D}$-serine release provides a novel means to activate N-methyl-Daspartate receptors. J Biol Chem 281:14151-14162.

Kim PM, Aizawa H, Kim PS, Huang AS, Wickramasinghe SR, Kashani AH, Barrow RK, Huganir RL, Ghosh A, Snyder SH (2005) Serine racemase: activation by glutamate neurotransmission via glutamate receptor interacting protein and mediation of neuronal migration. Proc Natl Acad Sci U S A 102:2105-2110.

Kostrzewa RM, Kostrzewa JP, Brown RW, Nowak P, Brus R (2008) Dopamine receptor supersensitivity: development, mechanisms, presentation, and clinical applicability. Neurotox Res 14:121-128.

Lipton SA (2006) Paradigm shift in neuroprotection by NMDA receptor blockade: memantine and beyond. Nat Rev Drug Discov 5:160-170.

Mohn AR, Gainetdinov RR, Caron MG, Koller BH (1999) Mice with reduced NMDA receptor expression display behaviors related to schizophrenia. Cell 98:427-436.

Mustafa AK, Kumar M, Selvakumar B, Ho GP, Ehmsen JT, Barrow RK, Amzel LM, Snyder SH (2007) Nitric oxide $S$-nitrosylates serine racemase, mediating feedback inhibition of D-serine formation. Proc Natl Acad Sci U S A 104:2950-2955.

Mustafa AK, van Rossum DB, Patterson RL, Maag D, Ehmsen JT, Gazi SK, Chakraborty A, Barrow RK, Amzel LM, Snyder SH (2009) Glutamatergic regulation of serine racemase via reversal of PIP2 inhibition. Proc Natl Acad Sci U S A 106:2921-2926.

Nong Y, Huang YQ, Ju W, Kalia LV, Ahmadian G, Wang YT, Salter MW (2003) Glycine binding primes NMDA receptor internalization. Nature 422:302-307.

Vallance P, Leiper J (2002) Blocking NO synthesis: how, where and why? Nat Rev Drug Discov 1:939-950.

Wolosker H (2006) D-serine regulation of NMDA receptor activity. Sci STKE 2006:PE41.

Zeynalov E, Doré S (2009) Low doses of carbon monoxide protect against experimental focal brain ischemia. Neurotox Res 15:133-137. 